\title{
MOTIVATIONS TO FORM A MAJORITY COALITION OF CANDIDATES MACHFUD ARIFIN AND MUJIMAN IN THE SURABAYA CITY ELECTION IN 2020
}

\author{
Moh. Ainul Yaqin
}

Mahasiswa Pascasarjana IImu Politik Universitas Indonesia

\begin{abstract}
The formation of a coalition of political parties in the regional head election is an interesting phenomenon to be studied, as was the case in the 2020 Surabaya City Election. The process of forming a coalition of political parties with the majority supporters of Machfud Arifin - Mujiaaman. Thus, this study analyzes the process of forming political party coalitions in the 2020 Surabaya City Election. This study uses Geoffrey Pridham's motivational theory of coalition formation regarding the factors that can influence the formation of political party coalitions, political coalition theory by William Riker which emphasizes (minimum winning) coalition) and rational choice theory to see the basic interests of the actors in determining the coalition. This study uses a qualitative approach, with interview data collection techniques and documentation studies. The findings of this study indicate that the process of forming a coalition supporting Machfud Arifin - Mujiaman begins with a strategic discourse between Gerindra, PKB, PAN, NasDem, PPP, Golkar, Democrats, and PKS which is oriented towards a tactical orientation to subvert the dominance of PDIP power in Surabaya. These parties basically have the same spirit because post-reform Surabaya has always been dominated by leaders from the PDIP. Machfud Arifin is considered a potential candidate because he has the financial strength, political networks, and inter-party lobbying in building coalition partners. Machfud Arifin became a trigger in the process of forming the coalition. In the process, horizontal-vertical dynamics occurred, because each party encouraged its cadres to become Machfud Arifin's companion. Thus, theoretically, the process of forming a coalition supporting Machfud Arifin Mujiaman is influenced by three basic things, namely ideological factors which are the initial thoughts of the majority party which emphasizes leadership renewal, then the historical party that has existed since before 2020 elections were held and finally pragmatic factors ambition to gain power by merging eight political parties. In addition, political actors carry Machfud Arifin with rational choices, that first is the electability survey number, financial capital, and political network owned by the candidate. The coalition is dynamic, so it requires the same commitment and vision, as well as conflict management mechanisms to maintain the integrity of the coalition of political parties.
\end{abstract}

Key Words: Political Coalition, Pilkada 2020, Machfud Arifin, Surabaya 


\section{A. Introduction}

Surabaya election was followed by two candidate pairs of Mayor and Deputy Mayor. First, the pair of candidates Eri Cahyadi and Armuji supported by the Indonesian Democratic Party of Struggle (PDIP) in coalition with the Indonesian Solidarity Party (PSI), with the number of seats of these two parties in the Surabaya city parliament reaching 19 seats. Eri Cahyadi has a background of bureaucrats with the last position of head of the city development planning Agency (Bappeko) Surabaya. However, due to his closeness to Mayor Tri Rismaharini, Eri Cahyadi was encouraged to be submitted as a candidate for mayor through the PDIP. Meanwhile, Armuji is a PDIP cadre who has served as Chairman of the Surabaya DPRD and most recently as a member of the East Java provincial DPRD from 2019 to 2024.

Furthermore, his opponents are candidate pairs of Machfud Arifin and Mujiaman Sukirno who are supported by a coalition of 8 political parties namely Golkar, Democrat, PKS, PKB, PAN, Nasdem, Gerindra, and PPP, with a total of 31 seats $(62 \%)$. Machfud is a retired police officer with the last rank of two-star general and the last post as head of the provincial police (KAPOLDA) of East Java in 2018. Machfud has been involved in politics since the 2019 presidential elections as the chairman of the East Java regional campaign team of candidates Joko Widodo and Ma'ruf Amin. While the pair of candidates for deputy mayor of Mujiaman are recorded to have served as the Director of Municipal Waterworks (PDAM) Surya Sembada Surabaya city.

The political phenomenon becomes interesting if you look at the map of the strength of the coalition of political parties supporting Machfud - Mujiaman which has the support from the majority party with a coalition of eight political parties. When viewed from the experience of the implementation of elections in some areas, candidates carried by large coalition do not always result in victory. Meanwhile, Nurhasim (2018) mentioned other considerations in forming a coalition of parties by cooperating with the majority party because by creating a single 
candidate, the chances of winning the competition are greater. Political parties then assemble in a coalition regardless of ideology, party platform, party policy, and other rational reasons.

Table 1.1

The map of political parties based on the Surabaya city parliamentary seats DPRD 2019-2024

\begin{tabular}{|l|l|l|}
\hline Political party & Seats & Votes \\
\hline PKB & 5 seats & 153.509 votes \\
\hline Gerindra & 5 seats & 128.016 votes \\
\hline PDIP & 15 seats & 418.872 votes \\
\hline Golkar & 5 seats & 115.129 votes \\
\hline Nasdem & 3 seats & 86.264 votes \\
\hline PKS & 5 seats & 116.137 votes \\
\hline PPP & 1 seat & 56.242 votes \\
\hline PSI & 4 seats & 90.758 votes \\
\hline PAN & 3 seats & 78.263 votes \\
\hline Demokrat & 4 seats & 119.783 votes \\
\hline Total & 5 seats & \\
\hline
\end{tabular}

Source: kpu-surabayakota.go.id

Officially the coalition of parties supporting Machfud Arifin and Mujiaman declared itself on January 26, 2020, at the Machfud Arifin Center, Surabaya. The declaration is still followed by five political parties, namely PKB, Gerindra Party, Democratic Party, PAN, and PPP. The five leaders of the Surabaya citylevel party read out the declaration by promising to win the pair Machfud Arifin and Mujiaman. A week before the declaration, the chairman of DPW PAN Jatim, Masfuk, had submitted a letter of recommendation from the level of DPD 
Surabaya city, DPW Jatim to DPP PAN to Machfud Arifin. PAN is widely left entirely to Machfud Arifin to choose a candidate for deputy mayor who will accompany him. Machfud is expected to provide significant changes in the development of Surabaya City. After the declaration, following three more parties finally provided support, namely Golkar, Nasdem, and PKS. Golkar initially felt disappointed because Machfud Arifin did not choose the recommendation representative. Nevertheless, Golkar promised to remain under the commitment to continue to support the Machfud Arifin and Mujiaman candidates in the 2020 simultaneous regional head elections.

In addition to political parties, the role of candidate pair has a major appeal in the formation of coalitions. Machfud Arifin as a central figure in the nomination process is inseparable from the political negotiation process until the party's decision in providing support until the formation of a coalition. The eight parties weighed heavily on the background of candidate pairs to offer to constituents at the election.

Eight political parties of the Machfud Arifin-Mujiaman supporting coalition are believed to have a political agreement on the direction forward if the backed candidate wins. The agreement can certainly be a policy or something else that is an advantage for each party, Nurhasim (2018). Therefore, according to the researchers, there is one trigger that is a strong reason for eight supporting parties that ideologically have many differences and then decide to be a part of a coalition. Meanwhile, on the other hand, the PDIP which has 15 seats in the DPRD, and can submit candidates without a coalition, takes longer to determine candidates. Many political observers consider that the DPP wants Wishnu Sakti Buana who is also the current deputy mayor, while Tri Rismaharini as mayor prefers Eri Cahyadi to continue his leadership (JawaPos, 30/8/2020).

Geoffrey Pridham in his journal explained that the coalition of political parties began to be widely carried out after the second world war in parts of Europe. Based on the simple application of the mathematical model, this theory is operated on a general rational assumption, which is motivated by the decision-making process. This means that political parties unite as a coalition of 
political actors. The goal of the coalition government should be to command majority support in the legislative element. Parties are motivated by either power (holding office) or basic policy objectives, or even both. Meanwhile, the coalition movement character of the political elite tends to justify all means to achieve power. The coalition can be interpreted as joining for and coalition in this understanding is the merger of political parties to attract candidates in the hope of power-sharing. The coalition does not mean the incorporation of ideology, but only its physical form, so it can be said that the coalition is only momentum or accidental, furthermore, the characteristic of the coalition may not be settled. However, the coalition does not mean the occurrence of powersharing, since it is very dependent on the government system. Therefore, the coalition will be beneficial if the government system used is parliamentary, but will be dependent heavily on the presidential system. In this case, researchers will analyze what the process and motivation of coalition formation in the election will be like.

From the above description, this study is intended to examine how the motivation of the formation of the major political parties of the coalition who were supporting the Machfud and Mujiaman pair. Broadly speaking, this research illustrates the process of forming a coalition of political parties with majority seats (oversized) that supports Machfud Arifin - Mujiaman in the Surabaya election, along with its factors behind the process of forming the coalition.

\section{B. Theoretical review}

\section{Election}

Since the ancient Greek era, the democratic political system has been a good and rational option when used in the system of government of a modern country. It is because democratic values are a system that can accommodate the interests and rights of everybody within a country. In a democratic system, a leader wants to be elected by the people either through direct elections (direct democracy) or through a representative system (indirect democracy). However, in 
modern times of today's elections, they are indirectly an alternative that seems suitable for both modern citizens and the complexity of the case and territoriality of a country.

'Miriam Budiardjo (2009) said election or the electoral system is considered as a symbol, all benchmarks of democracy. Thus, there is no country in this world without elections that are viewed as a democratic country. Multiple countries that practice totalitarian, authoritarian regimes such as Middle Eastern countries instead flock to a democratic country.

A democratic country can be identified in the process of power rotation through the electoral system. Elections are the method of translating the vote in an election into seats won by a party or candidate (Kacung Marijan. 2010). The election itself is divided into several levels, namely presidential, legislative, governor, and mayoral elections. It continues to be a lot of votes won by political parties which are equal to the seats obtained by a particular party if the electoral system uses a system of proportion, such as Indonesia, the Netherlands, and France.

However, it would be different if the electoral system of a country uses a district system, such as America, Britain, and Malaysia. In this context, the democratic system must always look for a format that is compatible with the socio-cultural of a country, both political culture and its best context. Democracy is a process, not a form that has ended. It refers to dynamic activities, moving continuously, never stopping (Tjahjo Kumolo. 2015).

\section{Political parties}

In modern political thought, the existence of political parties is a necessity as well as an important asset of a country. Political parties have a strategic position and function in building a democratic government system. Universally, a political party might be seen as an organized group, whose possess the same orientation, values, or ideals (Miriam Budiarjo; 1998). Through this interpretation, each 
political party certainly has the same ideals from all its administrators and their respective cadres.

The universal goal of the party must gain power, support (voters) in the political or electoral process. By getting a lot of political support (voters), political parties will gain constitutional power and become the ultimate goal of a party being founded. Indeed, modern politics is party politics. They are the main actors in the system linking citizenship to the government process. Political parties sort out various wills of citizens, most of which are revealed through interests in various groups or the mass media (Paul. A. Sabatier. 1999). The arrival of political parties as state assets is indispensable in modern democratic life in the process of legal power rotation. However, political parties have also been adopted by political regimes that do not understand elections and parliaments, where the only candidate is offered as a candidate for selection, or where only one party occupies the legislature (Maurice Duverger; 1981).

We can observe the application of quasi-democracy in several countries with socialist-communist ideologies. From the Indonesian context, it happened during the new order regime. The Golkar party, which belongs to the government, had always dominated representatives in parliament, up to the power structure of one political party. This condition shows that the arrival of political parties can be adopted in various political regimes of a country.

\section{Research Methodology}

This study used a qualitative approach with the research problem aimed at obtaining an in-depth and comprehensive description of a phenomenon felt by the research subject, for example, attitudes, assumptions, motivations, and some others holistically, along with the descriptive methods in the form of words and language in a natural specific context (Moleong, 2008). The approach used was tacit knowledge of the research problem which intended to describe the research results and create a reflection even in a certain condition. The 
knowledge that is in the brain of a person was following the description and experience of the person himself. Generally, this insight is unstructured, difficult to define, and communicated in an official language to others. Its contents also included individual descriptions. This knowledge is usually not documented because it is still one's mind. This approach was chosen because the phenomenon under study is a case that requires an in-depth quality descriptive study (Moleong, 2008). For Yin (2013), the problem study approach can be defined as an empirical inquiry activity that investigates phenomena in a real-life context, when the boundaries between phenomena and context are not clearly visible and multiple sources of facts are utilized. The problem research approach is suitable to be used to explore the why or how of a phenomenon (yin, 2013).

In this study, the phenomenon that wants to be explored was the motivation behind the formation of a coalition of the majority parties carrying Machfud Arifin - Mujiaman in the 2020 Surabaya city election.

\section{Analysis and Discussion}

In the constitution law number 8 in 2015 about the election of governors, regents, and mayors was described that the registration of candidates for regional leaders must go through a political party with a letter of recommendation signed by the central administrator (DPP). This means that even though regional party administrators have decided which candidates will be promoted in the Pilkada, the final decision lean on the party's DPP. Although the regional administrators may notice the dynamics and the political map in the region, all of them will be meaningless since the DPP already has its decision. The magnitude of the role of the DPP requires the DPD to only act as a decision-maker in the nomination of candidates for regional heads. For instance, the process of selecting candidates by the DPD may not have a binding decision since they still have to perform political lobbying in the DPP. This recommendation from the party's DPP is used to persuade the prospective candidates who need the means to form a coalition. 


\section{Discourse on the establishment of a strategic coalition}

In mid-2019, the political constellation began to form; the parties began to be more dynamic, formulating an agenda or strategy to welcome the momentum of 2020 local elections in Surabaya. The leadership of the city which has long been controlled by the ruling party, namely PDIP, emerge the new leadership discourses for Surabaya. However, in general, political parties were oriented to win in the Pilkada. So that the discourse was not very significant, due to the dominant power of the PDIP was indeed difficult to overthrow, both in the context of popularity, electability, and established political capital.

The strength of the PDIP does not mean that the political constellation and dynamics are stagnant. The discourse of a change of leadership in Surabaya to create a new figure as Mayor of Surabaya is getting more massive, as the Pilkada process goes on. This condition made the parties outside the PDIP, namely Gerindra, Golkar, NasDem, PAN, PKS, Democrat, PKB and PPP begin to count the power in the DPRD to seize power. Eight political parties realized that the votes obtained in the previous elections were not able to carry out candidates independently. On this basis, the parties need strength through a coalition.

Pridham (1987), the concept can explain the formation of a dynamic and coalition process of political parties. In the coalition process, political parties tend to be more considerate of several factors used in understanding the coalition process, the dimension used is the motivational dimension. The basic essence of this dimension is that a coalition between political parties can be formed on two things, namely based on policy closeness (trade-off) between the objectives of "office seeking" and commitment to a policy. For example, the motivation among coalition partners on policy issues, how far the priority of the issue can relate to strategy or party identity. 
At this point, the coalition occurs based on the closeness of policies and the same goals between parties.

In the process, to win the Pilkada and overthrow the power of the PDIP in Surabaya, a candidate who is qualified and has a high chance of victory is needed. At first, the Gerindra Party opened the widest possible netting to see all potential candidates from both cadre and non-party elements. The registration, which was opened from October 25 to November 15, 2019, favored the name Machfud Arifin as a candidate for mayor. Thus, DPD Gerindra Surabaya saw that there were several prospective candidates from non-party cadres who participated in this momentum. Apart from candidates, political parties as political machines in Pilkada need to be prepared as well as possible. If only Gerindra itself nominates a candidate, then it will not meet the initial prerequisite, namely a minimum of $20 \%$ of the votes in the DPRD seats to nominate a candidate. Thus, it is important to pay attention to the coalition partners of political parties, both in the context of the number of seats acquired in the DPRD, the mass base in the regions, as well as the image of political parties.

Although not openly, several parties have also opened registration for prospective candidates, such as PAN, NasDem, and Golkar. However, the name Machfud Arifin always appears as the runner-up in every party. Therefore, the parties made a ranking and finally agreed to carry Machfud Arifin. The idea of reforming Surabaya by political parties, especially in the context of its government leadership, is identified with the figure of Machfud Arifin. So that his figure is considered the most appropriate as an effort to overthrow the power of the PDIP.

It can be understood that the motives of the eight parties are how these parties can overthrow and seize power from the PDIP. Interest in the aspect of power alone can be said as a pragmatic step from political parties. In this context, Efriza (2012) argues that coalitions formed based on pragmatic interests, namely to gain power solely are 
called tactical coalitions. This coalition pattern can be formed because nothing but a coalition is a tool or strategy that is quite effective in gaining power and gaining votes.

If we examine further, the discourse of renewal in Surabaya is the response of the parties to the socio-political conditions that have occurred over the years in Surabaya. The leadership of Surabaya has been controlled by a single party, namely PDIP for almost 20 years. Mahfudz, Deputy Chairperson of the Surabaya PKB DPC, said that during the time PDIP was in power in Surabaya, many mayoral policies benefited its cadres. Even the lowest power structures, such as RT/RW, are mostly filled by PDIP cadres and sympathizers. The political method used by PDIP has always benefited the party in every election. So from this anxiety, the political parties felt that there was a common ground to overthrow the power of the PDIP in Surabaya by bringing up a potential candidate, namely Machfud Arifin.

As Pridham (1987) argues that socio-political factors are sociopolitical issues in the area that can build a frame or common interest so that a coalition is formed. Thus, the spirit that became the meeting point for the parties was in the figure of Machfud Arifin to overthrow the power of the PDIP by building a coalition and winning the 2020 Surabaya Pilkada. In addition, the plan of a grand coalition was never thought of before. Machfud Arifin initially only wanted to cooperate with the party as needed as a condition to run in the Pilkada. However, because the parties felt that their figures could represent the political interests of the parties, what happened was the formation of a large coalition so that the chances of victory could be achieved.

Apart from having a greater potential for victory, other political parties will also be interested in forming a coalition with parties that have a large mass base or a large number of voters. So that it can realize the Grand Coalition, namely a large coalition consisting of several winning political parties (Ihsan, 2011). So that the design of the Surabaya renewal policy in urban development can be more 
effectively realized with the collective power built through the coalition of political parties. Thus, this approach emphasizes more on policybased coalitions, namely coalitions formed based on the interests of political parties' policies or ideological programs that can be implemented together with other political parties. Efriza (2012) argues that coalitions formed based on the interests of the vision and ideology of political parties are called strategic coalitions.

In another theoretical perspective by Arend Lijphart (1984), this analogizes in a straight line. Political parties on the left of the line are parties with a left ideological spectrum. Furthermore, the political parties to the right of the line are parties with the right ideological spectrum. While the political parties in the middle of the line are political parties with a middle ideological spectrum. That is, the more to the left of a political party, the more secular the party is. On the other hand, the more to the right a party is the more religious it will be. The basic assumption of this theory is that the parties are in a coalition because each has closeness in its policy orientation. The parties will seek coalition members from the closest party ideologically, which is itself reflected in the party's policy orientation. Political parties are not only joined to seize power but also really consider the closeness related to the policies of each party (Cipto, 2000).

However, the difference in platforms does not mean dismissing the discourse of a strategic coalition between the eight parties. In this context, the strategic coalition aspect can be described from the similarity of the parties' perspectives in assessing the regulations made by the incumbent. The assessment resulted in the conclusion that the regulations made by the incumbent have not been able to realize the welfare of the people of the City of Surabaya. So that the eight parties have their programs that can be harmonized, the orientation of the coalition is built based on the similarity of programs 
or development visions that will be implemented in the city of Surabaya.

\section{The Similarity of Platforms for Machfud Arifin's Coalition Party - Mujiaman}

Robert Axelrod explained that coalitions of political parties should be formed in a connected manner, namely consisting of parties that are the same on a policy scale and exclude partners that are not important. Coalition based on common policy objectives is more important and stable than on the basis of numbers. It is intended that the former government can minimize conflicts of interest between fellow coalition members. Meanwhile, Riker assessed that the coalition is based on coalition goals or is office seeking (maximizing power), while Axelrod emphasizes parties as policy seeking (implementing policies according to party programs). The policyseeking aspect emphasizes the loyalty of coalition members. But if based solely on size, loyalty tends to be low, depending on the extent to which the profit-sharing in the coalition can be shared among all coalition members. So what is important is how coalitions can be built to carry out certain programs, not just to win or seize power.

If the coalition of political parties Machfud Arifin is seen from Axelrod's thinking, it needs to be observed based on several aspects of common ground. First, whether the party coalition is formed based on carrying out certain policy programs that can be a tool to achieve the objectives of implementing political party programs. This means that the coalition is not only based on ideological similarities but rather on the similarity of the programs that are carried out. The parties then agreed to join a coalition that carried a figure who could represent and run the program.

However, simply, the Machfud Arifin coalition was built without paying attention to the closeness of policy preferences, especially in practice the issue of party ideology is rarely a concern. The eight parties ideologically have many striking differences. Like PKB, which 
has a religious-nationalist direction, traditional Islamic tendencies with a mass base of Nahdlatul Ulama (NU) identical with love for the Pancasila state, can accept differences with PKS which have Islamic orientation, but the agenda tends to implement Islamic law in Indonesia. It is also found out in the other parties, such as PAN, Gerindra, Golkar, Democrats, NasDem, and PPP. Therefore, with this description, Axelrod's theory of political parties as a policy seeking by building coalitions based on policy preferences is difficult to apply in the case of the coalition supporting Machfud Arifin.

For example, Gerindra, the party that carries the spirit of nationalism, has supported Prabowo Subianto in two presidential elections against Joko Widodo. However, to get closer to power, Gerindra is now supporting Jokowi's government with Prabowo as defense minister. This also applies retroactively downwards at the regional level. Gerindra supports Machfud Arifin, who was previously the chairman of Jokowi's Regional Campaign Team in East Java. Gerindra's pragmatic interests are evident in the coalition's axis. Based on the phenomenon that happened through the 8 parties, they seem solid but less of the succinctness in the effort to perform a serious candidate selection process.

The selection of prospective candidates seems to be just a formality to attract public sympathy. They seem to have no a single candidate who is encouraged even though he is only a candidate for deputy candidate for Machfud Arifin. Like Zahrul Azhar Asumta, who was clearly encouraged by Gerindra and Golkar as Machfud Arifin's representative, in the end, he was not chosen because he wanted to maintain the solidity and synergy of the coalition. Pridham (1987: 374) explains that there are internal party factors that explain the decisionmaking mechanism of political parties, whether it is to determine candidates or coalition partners.

Axelrod's thoughts can describe coalitions of political parties and their relation to issues of ideological or pragmatic considerations. But 
Riker's thinking tends to be pragmatic, while Axelrod emphasizes the ideological side of the coalition. Pragmatic tendencies are stronger than ideological preferences in coalition formation. In the end, the coalition has not been built on the common interests of the parties that are policy seeking or fighting for policy programs for the benefit of the people at large. Coalitions are still being formed by highlighting the aspect of gaining power (office seeking), namely parties tend to aim to maximize what they can take advantage of the moment of regional head elections.

Although office seeking is more relevant at the national level because there is a division of positions in the cabinet. However, the interests of political parties from the center also have continuity in the regions, for example, to secure the vote base in the regions. As in the case in the 2017 Cimahi Pilkada, there was a majority coalition based on office seeking against the incumbent because they wanted to secure a national project in the form of a high-speed train crossing the area. This means that the intertwined interests between the center and the regions make it impossible to distinguish between the regional and central coalition patterns. The size of the party becomes unimportant, both large and small parties aim to maximize their power in the capacity of each of the small parties to function themselves as fulfilling requirements.

Ideological factors, interests, and power are usually always attached so that the party was founded to accommodate these three things. However, political parties are often office seeking because that is what is attached to political parties in gaining power. Party ideology can be used to guide the actions of reason and interests that change over time. In reality, party ideology is only used as a differentiator, but it has not become an identity where constituents can identify themselves with other parties.

Party coalitions are not easy to predict because parties on the left or right spectrum are not always in coalition with their immediate 
neighbors. The tendency that often occurs is that parties can form a coalition with any party as long as the interests of maximizing power can be achieved. For political parties, the issue of policy preferences that will be fought for has not become an urgent agenda because their constituents often do not pay attention to it.

\section{The historical foundation of Machfud Arifin's party coalition with} Mujiaman

Historically, the coalition supporting Machfud Arifin has a common thread. The Golkar Party, for example, through its faction in the Surabaya City DPRD at the end of 2019, discussed using the right of interpellation because they were disappointed with the treatment of Mayor Risma Triharini who did not welcome the agenda of the Minister of Youth and Sports who is also a senior Golkar politician, Zainuddin Amali when he wanted to carry out a surprise inspection. ) at Gelora Bung Tomo (GBT) on Sunday (11/3/2019). The inspection was carried out by the Minister of Youth and Sports to check the readiness of the stadium which will become one of the venues for the U-20 World Cup in 2021. Unfortunately, at that time the stadium door was tightly locked. Along the way, they plan to apply for the right of interpellation by the Golkar faction was not only due to the failure of the Menpora's inspection agenda to Gelora Bung Tomo, but also based on the inability of the City Government to welcome highranking state officials in its territory.

The political constellation in Surabaya is starting to warm up ahead of the 2020 Pilkada. Golkar is trying to get the public's attention on this issue. In addition, many observers believe that this effort is intended to reduce Risma's image at the end of her leadership. Meanwhile, Risma was defended by PDIP as the supporting party in the 2010 and 2015 regional elections. The PDIP faction asked the Golkar faction to sit down together to discuss the issue. The chairman of the PDIP faction at that time, Syaifuddin Zuhri, 
announced that he would go all out behind Risma if there was an interpellation. Syaifuddin tried to explain to the public that the incident was motivated by a lack of communication between the Menpora and the City Government. According to him, the inspection activity by the Minister of Youth and Sports was carried out at the wrong time, namely a holiday. However, it didn't take long for the drama of the debate over the right to interpellation with Mayor Risma to end. The Golkar faction and the Surabaya City Government chose to make peace after deliberation and mediation by the leadership of the Surabaya DPRD.

From the phenomena above, it is not surprising that in the 2020 Pilkada, Golkar is trying hard to nominate a candidate for mayor other than the candidate raised by PDIP. Golkar felt that it would be impossible to defeat PDIP if it did not combine the great power of the political parties. Arif Fathoni, Chairman of the DPD Golkar Surabaya, said that the only way to win the Surabaya Regional Head Election is through a political coalition.

After the defeat of the parties in the 2010 Surabaya City Election to PDIP with the mayoral candidate Tri Rismaharini, the parties in the DPRD tend to choose to be passive and sometimes take an oppositional stance. This was proven when the 2015 Pilkada, 8 parties chose to abstain, which made the election almost postponed because the incumbent candidate had no opponents. Only PAN and Democrats finally brought in a candidate but had no ambition to win the election. The series of political events during Risma's tenure as mayor made the parties count their strength to unite against the dominance of the PDIP in the 2020 elections. In addition, the joining of PAN and PPP in Machfud Arifin's coalition is a form of active coalition, namely an ongoing coalition.

This is because PAN and PPP are one faction in the DPRD and have criticized Mayor Risma several times. For example, at the end of his term, Buchori Imron, the chairman of PPP in Surabaya and a 
member of the DPRD, stated that for 10 years Risma had failed to build the city of Surabaya, especially in the northern area because she did not have proper planning and DED (Detail Engineering Design) for every regional development, for example, the bamboo bridge that was built in the Mangrove Tourism Area, Wonorejo, Rungkut with a budget of Rp 1.2 billion which is not maintained and some parts of the sides are in a collapsed condition. Thus, it becomes natural for PAN and PPP to form a coalition during the Pilkada momentum.

\section{Pragmatic Motivation of the Coalition of Machfud Arifin - Mujiaman}

The idea of reforming Surabaya, especially in the context of its government leadership, was the first step for PDIP to build a coalition of political parties. This can be interpreted as an effort to subvert the incumbent power. So it can be understood that the motive of the coalition of parties supporting Machfud Arifin is how these parties can overthrow and seize power from the incumbent and the ruling party. Interest in the aspect of power alone can be said as a pragmatic step from political parties. In this context, Efriza (2012: 315) argues that coalitions formed based on pragmatic interests, namely to gain power solely are called tactical coalitions. This coalition pattern can be formed because nothing but a coalition is a tool or strategy that is quite effective in gaining power and gaining votes.

In the coalition that carries Machfud Arifin - Mujiaman, it can be said that there is a pattern of strategic and tactical coalitions in it. We can see this from the reasons for the parties to form a coalition. The motive that is built is the similarity of the vision of development and renewal of the City of Surabaya to the actual situation and regional aspects. As a strategic coalition that puts forward the ideological aspect, at that time the eight parties committed to forming a coalition. However, it is undeniable that as the political dynamics in the momentum of the 2020 Surabaya elections, Golkar changes its 
orientation and seeks to be more tactical. This can be seen when Golkar was disappointed when Machfud Arifin did not choose the name that was being pushed as his representative.

The pragmatic tactical coalition is reflected in the phenomenon of the coalition supporting Machfud Arifin. There is no complete commitment that allows the coalition to continue to survive, amid intense inter-party political lobbying. Although he was deeply disappointed because a Golkar cadre was not selected as a candidate for deputy mayor who accompanied Machfud Arifin, Golkar had no other choice. Diverting support, for example, is not possible while the PDIP has declared that it does not need a coalition to nominate candidates. Meanwhile, PPP considers that it is not enough just for electability capital. However, regarding the issue of political operational financing in the Pilkada process, it is an essential part that candidates must have.

This is in line with what is meant by Katz and Mair (in Ambardi, 2009) that political parties have collective interests so that coalitions can be carried out by putting aside the ideological aspect. Therefore, its formation is incidental, dynamic, and proportional. Thus, the motive of the Golkar coalition towards the end of registration is in line with Efriza's (2012) statement regarding tactical coalitions, namely coalitions formed because they are not based on policy considerations. Instead, the coalition can be formed because of an agreement between political parties and candidates regarding the operational financing they will receive during the winning process, as well as several other commitments, when the candidate wins, thereby gaining power.

This financial capital is the key to realizing the ambitions of the eight parties to overthrow PDIP's power. Through the financial capital owned by Machfud Arifin and Mujiaman, the parties believe they can increase the popularity and electability of candidates in Surabaya. In 
addition, with high financial support, it can build the political power of more established parties, whether it's building mass support.

The tactical patterns carried out by each political party indicate that the main interest of political parties in the Pilkada is to win. So that political parties can get various benefits from this victory, both strategically and tactically. In a strategic context, the ideological interests or programs of political parties can be accommodated, so that they can be implemented when the government takes place.

Meanwhile, in a tactical or pragmatic context, there are various incentives that political parties get after the Pilkada, such as benefits from political dowries and operational election wins. Then, if the candidate he carries succeeds in winning the Pilkada, regional political parties will receive party operational financing on an ongoing basis and can more freely access development project opportunities and government assistance in the regions. Thus, political parties can take advantage of the network of election winners to maximize their power in the government.

Machfud Arifin's journey to carry out political lobbying to form a majority party coalition has taken a unique path. Machfud Arifin became the figure who became the choice of the majority party amid the party's hesitation to bring up alternative candidates. There can be no doubt that the process of forming a coalition of the majority parties supporting Machfud Arifin and Mujiaman above shows that the figure of a candidate for mayor has a central role. Machfud Arifin was actively involved in the lobbying process until the formation of the 8 political parties that are members of the coalition. The following are Machfud Arifin's steps in building coalition forces:

a. Machfud Arifin applied to political parties to gain support as a candidate for mayor.

b. Machfud Arifin conducted internal party lobbying to obtain recommendations. He even lobbied the DPP. 
c. Funding for the pilkada stage conducted by political parties was secured by Machfud Arifin. Therefore, the political dowry which is generally used to buy letters of recommendation is indirectly allocated for the operational nomination.

This condition was confirmed by all political parties supporting Machfud Arifin that the candidate has an important role in forming the party coalition. Even communication between political parties was facilitated by Machfud Arifin. For example, when Machfud Arifin decided to choose Mujiaman as his running mate, it caused a lot of disappointment from several supporting parties. To keep embracing all parties that have supported him, he invited all coalition parties to get to know Mujiaman more deeply.

\section{The Motivation Level of the Majority coalition Machfud Arifin - Mujiaman}

The process of forming a coalition of political parties by Machfud Arifin is the performance of many interrelated parties with the same goal in the Surabaya City election. First, in terms of actors, the process of forming a coalition involves at least three actors, namely regional level administrators (DPD), prospective regional head candidates, and party DPP leaders/managers. More than that, the coalition is also based on several factors in its formation. Thus, the more coalition members, the more they accommodate their interests. Each party has its own motivation in the political coalition. However, motivation usually has almost the same tendency in building coalitions. The following is the level of motivation of the party coalition supporting Machfud Arifin - Mujiaman.

The degree of influence of the three factors will be described in this sub-section. There is a level that qualitatively has a low influence, meaning that without this factor the promotion of regional head candidates can still be carried out. The effect is not absolute, meaning that even if this factor is present, the impact is not too 
significant. Some factors have a moderate level of influence, meaning that these factors must exist to form a coalition. However, its influence is relatively dependent on the ability of the candidate for a regional head in managing his strategy and political lobbies. Finally, some factors have a high level of influence, meaning that they greatly determine the process of coalition formation and nomination. This factor is very significant in encouraging the presence or absence of a coalition and the figures to be nominated. To explain the level of influence of these three factors, the researchers explain in the following table:

Table 2:

The Motivation Level of the Majority coalition Machfud Arifin - Mujiaman

\begin{tabular}{|c|c|c|}
\hline Factors & processes & Level of influence \\
\hline Ideology & $\begin{array}{l}\text { 1. Party examine common } \\
\text { platforms for establishing a } \\
\text { coalition } \\
\text { 2. The party carries the same } \\
\text { vision in seizing power } \\
\text { 3. The party approaches the } \\
\text { candidate who can represent } \\
\text { the party's visions }\end{array}$ & $\begin{array}{l}\text { Low } \\
\text { In general, parties barely } \\
\text { maximize their } \\
\text { ideological motivation in } \\
\text { seizing power }\end{array}$ \\
\hline History & $\begin{array}{l}\text { 1. Inter-party has established a } \\
\text { relationship before the } \\
\text { election } \\
\text { 2. Between parties involved in } \\
\text { active coalition (one faction in } \\
\text { DPRD, has the same } \\
\text { position, for example, } \\
\text { opposition). }\end{array}$ & $\begin{array}{l}\text { High } \\
\text { Inter-party relations that } \\
\text { have been established } \\
\text { make it easy to form } \\
\text { coalitions }\end{array}$ \\
\hline Pragmatic & 1. Party oriented to seize power & High \\
\hline
\end{tabular}




\begin{tabular}{|l|l|l|}
\hline $\begin{array}{l}\text { 2. } \\
\text { Parties consider the level of } \\
\text { electability of candidates } \\
\text { (cadres and non-cadres) }\end{array}$ & $\begin{array}{l}\text { The party tends to } \\
\text { overthrow } \\
\text { established power. This }\end{array}$ \\
$\begin{array}{l}\text { 3. The party capitalizes on } \\
\text { profits in the elections. }\end{array}$ & $\begin{array}{l}\text { power motivation makes } \\
\text { it easy for parties to find } \\
\text { an agreement. }\end{array}$ \\
\hline
\end{tabular}

From the description above, it can be seen that the ideological platform does not have a significant influence. In fact, if the platform is used optimally, it can be an important reason for forming an ideal coalition. If the party can translate its party platform into campaign programs and policy initiatives, it will be an added value for the party. The problem is that the formation of party coalitions in the regional elections is very far from a programming problem. The party aims to gain power (office seeking) but at an advanced level, apart from gaining power, the party must also be able to utilize the power it has achieved to implement programs based on the party's platform (policy seeking). Machfud Arifin's coalition above was not affected by its success by favoring the party's platform. So this factor has almost no influence on the formation of the coalition.

The socio-historical coalition of Machfud Arifin has also been established from the actual local elections several times. In the 2015 regional elections alone, parties outside the PDIP chose to abstain from participating in the contest, except for the Democrats and PAN, which were still carrying their candidate pairs at the last second before the closing of registration for the extension period. At least this condition indirectly positions non-PDIP parties outside the government. This trip does not rule out the possibility if these parties gather strength to try hard to overthrow PDIP's power in the 2020 Pilkada.

It is this pragmatic factor that dominates the motivation of parties to try to select potential candidates to be promoted against any candidate promoted by PDIP. Realistically reading that to become a coalition leader one must have a high seat capital, then these parties no longer prioritize party egoism. The figure of Machfud Arifin who has a non-party background is considered a mediator 
between parties to be in the same position. The figure of Machfud Arifin has a high level of influence, especially if he has logistical or financial capital for the needs of community groups as well as empowering party networks.

In addition, the figure of a candidate for a regional head is the reason for the party to take rational action in maximizing its interests, potential resources owned. Understand the political behavior of individuals and institutions composed of influential individuals. According to many researchers, political power is a process of elite negotiation to stay in power as long as possible. Institutions have values and interests that are built on the struggles of the elite within them. So understanding how individuals think in making decisions is not the first part of understanding how power is exercised. Schumpeter and Anthony Downs with their economic backgrounds view politics as a game played by powerful people to secure their vested interests.

Rational choices try to see individual behavior in making decisions, they will try to maximize the benefits they will have when faced with existing choices. Individuals act to maximize their interests. Rational behavior can be identified by maximizing several choices. This approach sees that political decisions are reactions of individual behaviors in maximizing their interests. In any political negotiation process, rational action is the ability of the individuals involved to see what gains can be maximized, and what losses can be minimized. This economic behavior applies in political competition. Elections are seen as a process of exchanging interests between politicians and voters.

Each is positioned in the framework of maximizing their interests for purposes that are considered rational. Pilkada in this case is a new source of power, both financially and politically. Regional level administrators see an opportunity to be closer to financial sources, namely through the candidates they carry. On the other hand, the party sees that there is a need for funding that can be achieved through candidacy in the Pilkada. These interests meet with the figure of a candidate for a regional head.

\section{E. Conclusion}


Based on the results of research and discussion regarding the formation of a coalition of political parties supporting Machfud Arifin - Mujiaman in the 2020 Surabaya Pilkada. So it is known that the process of forming the Machfud Arifin Coalition is a discourse from parties outside the PDIP that echoes Surabaya's leadership renewal. As the election momentum approaches, the parties feel unable to produce the right figure from their respective cadres who are ready to be promoted as candidates for mayor of Surabaya. In addition, political parties have begun to map out political power in the DPRD which will be used as a reference in nominating candidates for mayor. This means that it is also important for political parties to recruit candidates. The average strength of parties that do not reach 20 percent of seats as a condition for carrying candidates requires political parties to build coalitions. While on the other hand, PDIP, which is the ruling party, already has $30 \%$ of the seats, automatically there is no need to form a coalition to nominate candidates. PDIP from the outset stated that it would confidently carry out the candidate pair to replace Tri Rismaharini independently. Such conditions further raised political tensions in Surabaya, which led eight parties in the DPRD, Gerindra, PKB, NasDem, PAN, PKS, PPP, and Democrats to formulate candidates as challengers to whoever the PDIP proposed.

The appearance of Machfud Arifin as a candidate was warmly welcomed by the eight parties. Machfud Arifin's popularity in Surabaya is considered an opportunity for parties to nominate him as a potential candidate. On the other hand, the electability survey puts the name Machfud Arifin very likely to win in the election if he gets a big political vehicle. PAN, for example, feels that the figure of Machfud Arifin is capable of defeating any candidate promoted by PDIP. In addition, PAN victory can be achieved if all parties unite or form an office-seeking coalition pattern to carry Machfud Arifin, meaning that the regional elections must be held head to head. The belief of the eight parties in carrying out Machfud Arifin is not only because of the leadership experience that has been honed during his career in the police force but also because of the network and financial capital that are considered qualified. It is undeniable that in the election contestation, it is the candidate who has to pay for the 
campaign process and so on. Most of the coalition member parties support Machfud Arifin asking for his commitment to participate in providing support to the party is facing the upcoming legislative elections. This means that the party with a minimum of seats hopes that with the figure of Machfud Arifin if he becomes mayor, he can contribute to helping increase the number of seats in the DPRD. The assistance can be in the form of financial or the influence of the figure of Machfud Arifin to attract voters to the supporting party.

Pridham (1987) states that motivation in coalitions can be seen from several very influential factors such as ideological (same platforms), historical, and finally pragmatic (power struggles) in the coalition formation process. The basic essence of this dimension is that a coalition between political parties can be formed on two things, namely based on policy closeness (trade-off) between the objectives of "office seeking" and commitment to a policy. Usually, the motivations among coalition partners converge on policy issues, how far the priority of these issues can relate to strategy or party identity. However, in the majority coalition, Machfud Arifin was built not paying attention to the closeness of policy preferences, moreover, in practice, the issue of party ideology is rarely a concern. The eight parties ideologically have many differences which in principle are sometimes at odds. So that the motivation of the coalition based on the platform has very little influence in the formation of the majority coalition of Machfud Arifin.

Meanwhile, on historical factors, the coalition party that carries Machfud Arifin has existed for a long time in Surabaya. That is, the parties position themselves in the same carriage. After the defeat of the parties in the 2010 Surabaya City Election to PDIP with the mayoral candidate Tri Rismaharini, the parties in the DPRD tend to choose to be passive and sometimes take an oppositional stance. This was proven when the 2015 Pilkada, 8 parties chose to abstain, which made the election almost postponed because the incumbent candidate had no opponents. Only PAN and Democrats finally brought in a candidate but had no ambition to win the election. The series of political events during Risma's tenure as mayor made the parties count their strength to unite in resisting the dominance of the PDIP in the 2020 Pilkada. In addition, there are 
active coalitions that have also joined to support Machfud Arifin such as PAN and PPP who are members of one faction in the DPRD.

Lastly, Machfud Arifin's coalition pattern is more dominant towards a pragmatic pattern. There is no complete commitment that allows the coalition to continue to survive, in intense inter-party political lobbying. For example, even though they were deeply disappointed because a Golkar cadre was not selected as a candidate for deputy mayor accompanying Machfud Arifin, Golkar still decided to support Machfud Arifin. Because in principle, Golkar only wants to win the election. However, Machfud Arifin lobbied the DPP to resolve the issue. The same thing happened in the bodies of other coalition member parties. Regarding the issue of political operational financing in the Pilkada process, it is an important part that candidates must have. Machfud Arifin as a candidate has that power.

That political parties have collective interests so that coalitions can be carried out by putting aside the ideological aspects. Therefore, its formation is incidental, dynamic, and proportional. Thus, the motive of the Golkar coalition towards the end of registration is in line with Efriza's (2012) statement regarding tactical coalitions, namely coalitions formed because they are not based on policy considerations. Instead, the coalition can be formed because of an agreement between political parties and candidates regarding the operational financing they will receive during the winning process, as well as several other commitments, when the candidate wins, thereby gaining power.

The following is a theoretical suggestion regarding what needs to be investigated further after the study on the formation of a coalition of majority supporters of Machfud Arifin in the 2020 Surabaya Pilkada. First, that the discussion regarding the coalition formation process is always related to various factors that influence the formation of a coalition. Thus, if there are other studies regarding the process of coalition formation, the analysis of this research will be more in-depth when using the theory of coalition formation factors as the main analytical tool. Second, the process of forming a coalition cannot be separated from the dynamics of carrying out candidates. In this aspect, the researcher did not explain in detail the motives of the candidate being promoted or running. 
Thus, the phenomenon of a person's political motives when running for public office is interesting when examined more deeply, and what concrete benefits are obtained by political parties during the process of winning a candidate and after the candidate succeeds in occupying the public office. Finally, this research focuses on how the dynamics of the coalition formation process are and what are the motivations behind coalition formation. However, it is interesting to investigate further the dynamics of the coalition of political parties after the election of regional heads. So that this research can describe how the movement of coalition members of political parties after receiving the final results of the Pilkada they participated in.

Meanwhile, practical suggestions are based on studies from the formation of a coalition of political parties supporting Machfud Arifin - Mujiaman in the 2020 Surabaya Pilkada. The formation of a coalition of political parties is always dynamic and proportional so that at any time it can change along with the political dynamics that occur in the region. Thus, a strategy is needed to maintain the integrity of the coalition of political parties. The strengthening of the coalition can be done if there are things that are the commitment of all coalition members so that they can become the foundation in forming a coalition of political parties. Then, all coalition members must have a framework of issues that make them have a common interest. Thus, the coalition is committed to achieving a common goal. After that, a mechanism is needed to reduce various kinds of differences. Furthermore, the process of forming a coalition is closely related to the influence of candidates who are contesting in the Pilkada.

Thus, the selection of candidates should be done with a rather long time before registration, for example, one year in advance. This is an effort to find the best candidate who will represent the party. If the prepared candidates are not close to the Pilkada agenda, then the map of the coalition of political parties can be more clearly defined. Then, the inauguration of the coalition should be held before approaching the candidate registration process. So that the coalition has more time to prepare other matters related to the need for winning in the Pilkada. Finally, if the candidate wins the Pilkada, the integrity of the coalition should be maintained, and coalition members will continue to try to attract other 
parties to join the government party, at least until the seats in the DPRD can be achieved by $50 \%+1$. This is aimed at realizing a strong and stable government without experiencing many obstacles in the parliament.

\section{References}

Almond, Gabriel A. (1990). A Discipline and Sects in Political Science, California: Sage Publications.

Ambardi, K. (2009). Mengungkap Politik Kartel. Jakarta: Gramedia

Budiardjo, Miriam. (2008). Dasar-dasar Ilmu Politik. Jakarta: Gramedia.

Cipto, Bambang. (2000). Partai kekuasaan dan militerisme. Yogyakarta: Pustaka Pelajar.

Cresswell, John. (1994). Research Design; Qualitative and Quantitative Approaches. London: Sage Publication.

Efriza. (2018). Koalisi Dan Pengelolaan Koalisi, Pada Pemerintahan Joko WidodoJusuf Kalla, IImu Politik di Sekolah Tinggi IImu Pemerintahan Abdi Negara (STIP-AN), Jurnal Politica Vol. 9 No. 1 Juni 2018.

Efriza. 2012. Political Explorer: Sebuah Kajian IImu Politik. Jakarta: Alfabeta.

Geddes, Barbara. (1994). Politician's Dilemma: Building State Capacity in Latin America, Berkeley: University of California Press.

Ihsan, A. B. 2011. Rekonstruksi dan Revitalisasi Koalisi dalam Sistem Quasi Presidensial. Jurnal Penelitian Politik, Menggugat Politik Parlemen, 1-32.

Lijphart, Arend. (1984). Democracies: Patterns of Majoritarian and Consensus Government in Twenty-One Countries, New Haven: Yale University Press.

Mahpudin, Abdul Hamid, Shanty Kartika Dewi. (2018). Dinamika Koalisi Partai Politik dalam Pencalonan Kepala Daerah pada Pilkada Banten 2017. Program Studi IImu Pemerintahan Fakultas IImu Sosial dan IImu Politik, Universitas Sultan Ageng Tirtayasa.

Marijan, Kacung. (2010). Sistem Politik Indonesia; Konsolidasi Demokrasi Pasca-Orde Baru. Jakarta: Kencana.

Michels, Robert. (1984). Partai Politik: Kecenderungan Oligarkis dalam Birokrasi. Jakarta: CV Rajawali.

Muhammad Hasan Saeful Rijal dan Wawan Ichwanuddin, "Dinamika Politik Internal Partai Golkar pada Masa Kepemimpinan Jusuf Kalla 2004-2009", Universitas Indonesia, 2015.

Nurhasim, Moch. (2018). Koalisi "Nano-Nano" Pilkada Serentak 2018. Jurnal Pusat Penelitian Politik-Lembaga IImu Pengetahuan Indonesia.

Nurjaman, Asep. (2018). Masa Depan Faksionalisme Politik Golkar Pasca Orde Baru, Jurnal Sospol, Vol 4 No 2 (Juli - Desember 2018), HIm 34-48.

Priddam, Geoffrey. (1987). "Coalition Behaviour and Party Systems in Western Europe: A Comparative Approach".

Putra, Rakhmad Hutomo, Proses Kandidasi Pasangan Rasiyo Dan Lucy Kurniasari Pada Pilkada Surabaya Tahun 2015, Jurnal 2016.

Ropik, Ainur, Alva Beriansyah, Wijaya. (2018). Rekrutmen Calon Kepala Daerah dalam Era Pilkada Langsung dan Serentak di Kabupaten Musi Banyuasin. Jurnal Intizar, Vol. 24, No. 2, Desember 2018, Hal. 273-281.

Samuel, Bob. Ketika Oligarki Menyandera Partai Politik: Studi Kasus Musyawarah Nasional Luar Biasa Partai Golongan Karya (Golkar) Tahun 2016. 
Departemen Politik dan Pemerintahan, Fakultas IImu Sosial dan IImu Politik, Universitas Diponegoro.

Susanti, Martien Herna. (2018). Dinasti Politik dalam Pilkada di Indonesia. Journal of Government and Civil Society, Vol. 1, No. 2, September 2017, pp. 111-119.

Volden, Craig \& Clifferd J. Carrubba. (2004). "The Formation Oversized Coalitions in Parliamentary Democracies", Dalam American Journal of Political Science, Vol. 48, No. 3, July 2004.

Winasih, Ni Wayan Indra, I Ketut Putra Erawan, Bandiyah. (2016). Peran Partai Politik dan Kalkulasi Elit Terhadap Karakteristik Koalisi (Studi Kasus : Pilkada Serentak di Kabupaten Karangasem dan Tabanan 2015). Fakultas ilmu Sosial dan ilmu politik Universitas Udayana. 